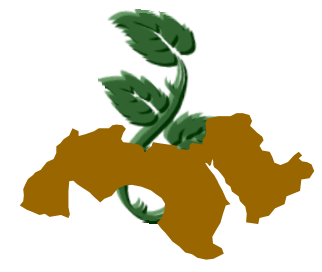

Arab Univ.

J. Agric. Sci., Ain Shams Univ., Cairo, 22(1), 43-54, 2014

\title{
THE EFFECT OF BIO-FERTILIZERS AND AMINO ACIDS ON TOMATO PRODUCTION AND WATER PRODUCTIVITY UNDER NET-HOUSE CONDITIONS
}

\author{
Hasanein, N.M. ${ }^{1}$; M.A.A. Abdrabbo ${ }^{2}$ and Y.K. El-Khulaifi ${ }^{1}$ \\ 1- Dept. of Agric. Res. and Extension, Management of Agricultural Affairs, \\ Ministry of Environment, Doha, Qatar \\ 2- Agro-Meteorology Res. Dept., Central Laboratory for Agricultural Climate, ARC. Giza, \\ Egypt
}

Keywords: Evatpo-transpiration, Delfan, Solanum lycopersicum and Water Productivity.

\section{ABSTRACT}

The present study was carried out during two successive seasons, 2011/2012 and 2012/2013, at the Agricultural Research Station; El-Otouria, Sheehaniya, Doha, Qatar; to investigate the response of two tomato cultivars (Isabella and Milas) to biofertilizers and amino acids. Two biofertilizer treatments, rizobacterien at a rate of 2 and 4 liter per feddan and one of amino acid (Delfan) at a rate of $200 \mathrm{ppm}$, were used. Chicken manure, at a rate of 10 tons/ feddan, was the control treatment. Results showed the superiority of Isabella compared to Milas in terms of vegetative growth and fruit yield. Using Rizobacterien at a rate of $4 \mathrm{li}$ ter/feddan plus Delfan (amino acids) at a rate of 200 ppm increased growth and fruit chemical characters, earliness and total yield. The average fruit weight per plant was significantly high under Rizobacteria at a rate of 4 liter/feddan plus Delfan (amino acids) at a rate of 200 ppm. The lowest vegetative growth, fruit and yield characters were obtained from Rizobacteria at a rate of 2 liter/feddan. The water productivity results showed that all treatments led to the increase of fruit yield. Isabella cultivar had higher water productivity than Milas cultivar. Using of Rizobacterien at a rate of four liter/feddan also increased the water productivity. The same trend was obtained by using Delfan at a rate of $200 \mathrm{ppm}$. Concerning water productivity, Isabella cultivar had higher water productivity 16.7 and $17.2 \mathrm{~kg}$ of tomato fruits per cubic meter of irrigation water $\left(\mathrm{m}^{3}\right)$ compared with
Milas cultivar which produced15.9 and $16.5 \mathrm{~kg}$ tomato fruits per cubic meter of irrigation water for first and second seasons, respectively. Isabella cultivar plus amino acid (Delfan) gave the highest water productivity 19.1 and $19.7 \mathrm{~kg}$ of tomato fruits per $\mathrm{m}^{3}$ water for first and second seasons, respectively compared the other treatments.

\section{INTRODUCTION}

Microorganisms, which are used as biofertilizers, induce simulative effect on plant growth and production by atmospheric nitrogen in a free living state e.g. Azotobacter (Saber, 1996; Awad., 1998). Numerous investigations stated that biofertilizations with different strains of bacteria induced significant increase in plant growth expressed as fresh and dry weight of different plant organs as well as number of leaves and branches and chemical compositions (Radwan 1983, on tomato; Kabesh et al 1987, on Soybean and Abdel Ati 1996, on potato.

The production of high yield vegetable crops requires that the soil must have favourable physical, chemical, nutritional and biological conditions. It is worth to mention that the good effect of biofertilizer inoculation improve root and plant growth parameters. In addition, adding biofertilizers increased population of soil microorganisms, especially in the surface layer at root rhizosphere, which stimulate plant growth (Awad, et al 1993). Many investigators emphasized the beneficial role of organic manures incorporated with biofertilizers to stimulate plant growth and vegetable crop yield, among them i.e., Abdalla, et al (2001) on pepper, Abou-Hussein (2002) on potatoes, Adam, et al (2002) on cantaloupe and Rizk, et al (2003) on 
squash. Many studies proved that foliar application of amino acid can improve the vegetative growth, physical parameters and fruit quality of chilli pepper (Maheswari et al 2004).

Tomato fruit yield and its composition responded significantly to biofertilizer applications. Kumaraswany and Madalageri (1990) mentioned that highest physical parameters and tomato fruit yield were gained by inoculating tomato plants with biofertilizers. Moreover, Shahaby (1993), Valpin \& Kapulink (1994), Terry et al (1995) and Awad et al (1998) obtained highest tomato fruit yield and chemical compositions with best fruit quality using various bacterial fertilizers. Hewedy, (1999) indicated that adding biofertilizer (Azotobacter) at a rate of 3 liters per feddan gave higher plant heights, physical parameters and fruit quality. Hasanein and Kabeel (2006) reported that using Rizobacterien, at a rate of 2 liters per feddan, significantly increases vegetative growth, chemical and physical parameters and total yield of potato crop. Proline amino acid was greatly synthesized within plant tissues more than other amino acids in grown plants and fruit for the protection against stresses (Batets et al 1999, Verranjaneyulu and Kumari, 2003). However, El-Shaabasi et al (2005) reported that the concentration of total amino acids increased plant height, leaf area and total yield of tomato plants. The same trend was reported by Ahmed et al (2006) who indicated that foliar proline amino acid at $100 \mathrm{ppm}$, on sweet pepper plants, gave the highest values of plant height, number of leaves, fruit length, average leaf area and total yield per plant. Hasanein and Gaafer, (2006) indicated that spraying free amino acids (Glutamic) at a rate of $200 \mathrm{ppm}$ increased plant height, chemical and physical parameters and total yield of watermelon crop.

The Food and Agriculture Organization (FAO, 1988) estimated that almost two-third of the increase in crop production needed in the next decades must come from higher yields per unit of land. The relationship between crop production and water received is called the crop-water production function. Moreover, good agriculture practices such as greenhouse cover, the use of microbial fertilizer, the use of amino acids can improve irrigation productivity via better plant growth and yield per water unit (Batets et al 1999; Verranjaneyulu and Kumari, 2003; Abdrabbo et al 2009). Abdrabbo et al (2007) mentioned that the use of good potato variety led to the increase in water productivity for water unit
The aim of the present study is to investigate the interaction effect, between the bio-fertilizer (Rizobacterien) and foliar application with amino acid (Delfan), on the vegetative growth, crop yield and quality of two tomato cultivars (Isabella and Milas).

\section{MATERIALS AND METHODS}

\section{Experimental Layout}

This study was conducted, at the Agricultural Research Station in El-Otouria, Sheehaniya, Doha, Qatar, during two successive seasons, 2011 and 2012. The experimental design was split plot with four replicates, having the cultivars at random in the main plot and biofertilizer treatments were randomly distributed in the sub plot. Each experimental plot consisted of raised bed, ten meters long and one meter width (two rows in each bed), and contained 40 tomato plants. The space between plants in each row was $0.5 \mathrm{~m}$. Tomato seeds were sown in the nursery on September 21th and 26th in 2011 and 2012, respectively. Seedling transplanting took place on October 19th and 23th in 2011 and 2012, respectively, under net-house conditions.

\section{1- Treatments}

The treatments were as follows:

A- Main plot:

a- Cultivar Isabella ( I)

b- Cultivar Milas (M)

B- Sub main plot:

a- Rizobacterien at a rate of 2 liter /feddan + Delfan (amino acids) at a rate of $200 \mathrm{ppm}(\mathrm{R} 1+\mathrm{D})$. b- Rizobacterien at a rate of 4 liter /feddan + Delfan (amino acids) at a rate of 200ppm (R2+D.(

c- Rizobacterien at a rate of 2 liter /feddan (R1).

d- Rizobacterien at a rate of 4 liter /feddan (R2).

e- Control Chicken manure at a rate of 10 tons per feddans $(\mathrm{C})$.

One Feddan $=4200 \mathrm{~m}^{2}$.

DELFAN is a brown liquid with $\mathrm{pH}$ of $5-5.5$ and specific gravity of $1.12 \mathrm{~g} / \mathrm{ml}$. It contains $18.4 \% \mathrm{w} / \mathrm{w}$ organic matter content, $10 \% \mathrm{w} / \mathrm{w}$ free amino acids, $3 \% \mathrm{w} / \mathrm{w}$ total nitrogen and $3 \% \mathrm{w} / \mathrm{w}$ organic nitrogen.

\section{C- Soil treatments}

Chicken manure and Rizobacteria were applied 20 days before transplanting date in the middle of 
the row at $20 \mathrm{~cm}$ depth from the soil surface. All experimental plots received the same water volume from transplanting till harvest using drip irrigation system. The flow rate of drippers was $4 \mathrm{~L} / \mathrm{h}$, the distance between the lateral irrigation lines was $150 \mathrm{~cm}$, and the distance between plants was about $35 \mathrm{~cm}$. All treated plants received 3 amino acid sprayings. The first was 30 days after planting, the second and third were performed after 21 days intervals with equal amount for each application. The amino acid treatments were carried out at early morning. Data of the physical and chemical properties of the soil are presented in Table (1).

\section{2- Measurements}

\section{A- Vegetative growth}

The vegetative growth parameters, plant height (cm) and leaf area (cm2), were measured from the 5th true leaf from the top (by Li 300 using laser leaf area meter produced by Li-Cor, Pinclivania). Total number of leaves per plant and the plant fresh weight (gm) were also recorded. Plant samples were dried in the oven, at $70^{\circ} \mathrm{C}$., to measure the plant dry weight (gm).

\section{a- Yield and its components}

The recorded yield parameters were early and total yield (kglplant), number of fruits per plant and average fruit weight.

\section{b- Chemical composition}

The Chemical composition parameters were measured as follow:-

\section{i-. Ascorbic acid (mg\100g fresh weight):}

It was measured by using 2, 6, dichloro-phenol indophenols according to A.O.A.C. (1990).

\section{ii- Total Titratable Acidity}

A random sample of $100 \mathrm{~g}$ fruit from each experimental plot at full ripe stage was taken to determine the total titratable acidity of juice by titration with $0.2 \mathrm{NaOH}$ (sodium hydroxide) solution using phenol phthalein indicator according to the method described in A.O.A.C. (1990).

\section{iii- Total soluble solids (TSS)}

It was determined using refract meter A.O.A.C. (1990).

\section{iv- Total chlorophyll content}

It was determined in sample taken randomly from the fourth upper leaf according to the A.O.A.C. (1990).

\section{Estimation of water requirements}

Potential evapotranspiration were measured by automatic weather station, allocated in the farm site. The water requirements was estimated based on FAO-56 method (Allen, et al 1998). Water requirement under net-house (Table 2) was calculated according to Hashem (2007). Leaching requirements of $25 \%$ were added to modify different water requirements.

Water productivity: It was calculated as follows: WP = Yield (Kg/plant) / Amount of water applied (m3/plant), according to Michael (1978).

\section{Statistical analysis}

Data were statistically analyzed using split plot design with four replicates. Each replicate consisted of 30 plants each seasons. The mean of different treatment were compared using the Least Significant Difference test (L.S.D.) at $5 \%$ level of probability (Gomez and Gomez, 1984).

\section{RESULTS AND DISCUSSION}

\section{A. Vegetative growth of tomato plants grown under net-house conditions}

Cultivar Isabella gave significantly higher plant height, leaf area, number of leaves, fresh and dry weight than cultivar Milas with significant effect during the two seasons (Table 3). Table (3) also showed that applying Rizobacterien at a rate of 4 liter/feddan + Delfan (amino acids) at a rate of 200 ppm increased plant height, leaf area, number of leaves, fresh and dry weight than the other treatments with significant differences. The second treatment that increased the vegetative growth parameters was rizobacterien at a rate of $4 \mathrm{li}$ ter/feddan. Similar results were found by Radwan (1983), Kabesh et al (1987), Awad et al (1993) and Abdel Ati (1996), Hewedy (1999), Verranjaneyulu and Kumari (2003), Maheswari et al (2004) and El- Shaabasi et al (2005). 
Table 1. Physical and chemical properties of the investigated soil.

\begin{tabular}{|c|c|c|c|c|c|c|c|c|c|c|c|c|c|c|}
\hline \multicolumn{15}{|c|}{$2011 / 2012$ season } \\
\hline \multicolumn{3}{|c|}{$\begin{array}{c}\text { particle size } \\
\text { distribution \% }\end{array}$} & \multirow[t]{2}{*}{ Texture } & \multirow[t]{2}{*}{$\mathrm{pH}$} & \multirow{2}{*}{$\begin{array}{c}\mathrm{EC} \\
\mathrm{dS} / \mathrm{m}\end{array}$} & \multirow{2}{*}{$\begin{array}{l}\mathrm{C} / \mathrm{N} \\
\text { Ratio }\end{array}$} & \multirow{2}{*}{$\begin{array}{c}\mathrm{Ca} \mathrm{CO} 3 \\
\% \\
\end{array}$} & \multicolumn{3}{|c|}{ macro nutrients } & \multicolumn{4}{|c|}{$\begin{array}{l}\text { micro nutrients in } \\
(\mathrm{ppm})\end{array}$} \\
\hline sand & Salt & Clay & & & & & & $\mathrm{N} \%$ & P ppm & $\mathrm{K} \mathrm{ppm}$ & $\mathrm{Fe}$ & $\mathrm{Mn}$ & $\mathrm{Zn}$ & $\mathrm{Cu}$ \\
\hline 69.28 & 6.00 & 24.7 & $\begin{array}{c}\text { salty clay } \\
\text { loam }\end{array}$ & 7.89 & 3.68 & 21: 1 & 24.9 & 0.18 & 168 & 230 & 10.9 & 11.9 & 13.2 & 3.30 \\
\hline \multicolumn{15}{|c|}{ 2012/2013 season } \\
\hline 67.3 & 4.00 & 28.7 & $\begin{array}{c}\text { salty clay } \\
\text { loam }\end{array}$ & 7.73 & 3.87 & 20: 1 & 23.2 & 0.19 & 160 & 277 & 8.5 & 12.2 & 11.3 & 3.61 \\
\hline
\end{tabular}

Table 2. Average daily water requirements (every 15 days) of tomato under green-house during 2011 /2012 and 2012/2013 seasons

\begin{tabular}{|c|c|c|c|c|c|c|c|c|c|c|c|c|}
\hline \multirow[b]{2}{*}{ Month } & \multicolumn{6}{|c|}{$2011 / 2012$} & \multicolumn{6}{|c|}{$2012 / 2013$} \\
\hline & $\begin{array}{l}\text { ETo } \\
\text { Open } \\
\text { Field }\end{array}$ & $\begin{array}{c}\text { ET } \\
\text { green- } \\
\text { house }\end{array}$ & $\mathrm{Kc}$ & ETc & $\begin{array}{l}\text { ETc Plus } \\
\text { leaching } \\
\text { fraction }\end{array}$ & $\begin{array}{l}\text { Water Req. } \\
\text { liter/ plant / } \\
\text { day }\end{array}$ & $\begin{array}{l}\text { ETo } \\
\text { Open } \\
\text { Field }\end{array}$ & $\begin{array}{c}\text { ET } \\
\text { green- } \\
\text { house }\end{array}$ & $\mathrm{Kc}$ & ETc & $\begin{array}{l}\text { ETc Plus } \\
\text { leaching } \\
\text { fraction }\end{array}$ & $\begin{array}{c}\text { Water Req. } \\
\text { liter/plant } \\
\text { /day }\end{array}$ \\
\hline \multirow{2}{*}{ October } & 4.43 & 3.10 & 0.45 & 1.40 & 1.74 & 0.94 & 4.30 & 3.01 & 0.45 & 1.35 & 2.42 & 1.31 \\
\hline & 3.89 & 2.72 & 0.50 & 1.36 & 1.70 & 0.92 & 3.79 & 2.66 & 0.50 & 1.33 & 2.37 & 1.28 \\
\hline \multirow{2}{*}{ November } & 3.35 & 2.35 & 0.60 & 1.41 & 1.76 & 0.95 & 3.29 & 2.30 & 0.60 & 1.38 & 2.47 & 1.33 \\
\hline & 3.08 & 2.16 & 0.75 & 1.62 & 2.02 & 1.09 & 2.91 & 2.04 & 0.75 & 1.53 & 2.73 & 1.48 \\
\hline \multirow{2}{*}{ December } & 2.81 & 1.96 & 0.90 & 1.77 & 2.21 & 1.19 & 2.54 & 1.78 & 0.90 & 1.60 & 2.85 & 1.54 \\
\hline & 2.65 & 1.86 & 0.95 & 1.76 & 2.20 & 1.19 & 2.64 & 1.85 & 0.95 & 1.76 & 3.14 & 1.69 \\
\hline \multirow{2}{*}{ January } & 2.49 & 1.75 & 1.10 & 1.92 & 2.40 & 1.30 & 2.75 & 1.93 & 1.10 & 2.12 & 3.78 & 2.04 \\
\hline & 2.95 & 2.06 & 1.15 & 2.37 & 2.96 & 1.60 & 3.14 & 2.20 & 1.15 & 2.53 & 4.52 & 2.44 \\
\hline \multirow{2}{*}{ February } & 3.40 & 2.38 & 1.20 & 2.85 & 3.57 & 1.92 & 3.53 & 2.47 & 1.20 & 2.97 & 5.30 & 2.87 \\
\hline & 4.01 & 2.80 & 1.10 & 3.09 & 3.86 & 2.09 & 4.08 & 2.85 & 1.10 & 3.14 & 5.60 & 3.02 \\
\hline \multirow{2}{*}{ March } & 4.62 & 3.23 & 1.05 & 3.39 & 4.24 & 2.29 & 4.62 & 3.23 & 1.05 & 3.39 & 6.06 & 3.28 \\
\hline & 5.15 & 3.61 & 1.00 & 3.61 & 4.51 & 2.44 & 5.00 & 3.50 & 1.00 & 3.50 & 6.24 & 3.37 \\
\hline \multirow{2}{*}{ April } & 5.69 & 3.98 & 0.95 & 3.78 & 4.73 & 2.56 & 5.38 & 3.76 & 0.95 & 3.57 & 6.38 & 3.44 \\
\hline & 6.32 & 4.43 & 0.85 & 3.76 & 4.70 & 2.54 & 6.03 & 4.22 & 0.85 & 3.59 & 6.41 & 3.46 \\
\hline \multirow{2}{*}{ May } & 6.95 & 4.87 & 0.65 & 3.16 & 3.95 & 2.14 & 6.69 & 4.68 & 0.65 & 3.04 & 5.44 & 2.94 \\
\hline & 7.10 & 4.97 & 0.50 & 2.49 & 3.11 & 1.68 & 3.35 & 2.34 & 0.60 & 1.17 & 2.09 & 1.32 \\
\hline \multicolumn{6}{|c|}{ Total } & 335 & & & Total & & & 552 \\
\hline
\end{tabular}


Table 3. Effect of biofertilizers and cultivars on vegetative growth of tomato plant leaves grown under net-house conditions

\begin{tabular}{|c|c|c|c|c|c|c|c|c|c|c|c|}
\hline & & \multicolumn{5}{|c|}{$2011 / 2012$} & \multicolumn{5}{|c|}{$2012 / 2013$} \\
\hline \multicolumn{2}{|c|}{ Treatments } & $\begin{array}{l}\text { Plant } \\
\text { height } \\
(\mathrm{cm})\end{array}$ & $\begin{array}{l}\text { leaf } \\
\text { area } \\
\mathrm{cm}^{2}\end{array}$ & $\begin{array}{c}\text { No. of } \\
\text { leaves } \\
\text { per } \\
\text { plant }\end{array}$ & $\begin{array}{l}\text { Fresh } \\
\text { weight } \\
(\mathrm{g})\end{array}$ & $\begin{array}{c}\text { Dry } \\
\text { weight } \\
(\mathrm{g})\end{array}$ & $\begin{array}{l}\text { Plant } \\
\text { height } \\
(\mathrm{cm})\end{array}$ & $\begin{array}{l}\text { leaf } \\
\text { area } \\
\mathrm{cm}^{2}\end{array}$ & $\begin{array}{c}\text { No. of } \\
\text { leaves } \\
\text { per } \\
\text { plant }\end{array}$ & $\begin{array}{l}\text { Fresh } \\
\text { weight } \\
(\mathrm{g})\end{array}$ & $\begin{array}{c}\text { Dry } \\
\text { weight } \\
(\mathrm{g})\end{array}$ \\
\hline \multirow[t]{2}{*}{$A$} & 1 & 511 & 348 & 62.9 & 1014 & 171 & 527 & 397 & 67.4 & 1114 & 190 \\
\hline & $M$ & 493 & 332 & 59.3 & 964 & 159 & 507 & 373 & 62.5 & 1022 & 178 \\
\hline & D. at 0.05 & 9.43 & 6.12 & 1.93 & 15.62 & 3.08 & 11.15 & 4.37 & 0.92 & 24.19 & 5.36 \\
\hline \multirow{5}{*}{ B } & $(\mathrm{R} 1+\mathrm{D})$ & 503 & 340 & 59.1 & 967 & 155 & 524 & 393 & 63.1 & 995 & 170 \\
\hline & (R2+D) & 575 & 438 & 75.5 & 1192 & 223 & 589 & 489 & 81.7 & 1281 & 249 \\
\hline & (R1) & 419 & 243 & 50.1 & 814 & 131 & 435 & 270 & 53.4 & 883 & 141 \\
\hline & (R2) & 546 & 396 & 65.7 & 1070 & 172 & 559 & 437 & 69.6 & 1230 & 206 \\
\hline & $\begin{array}{l}\text { (C) } \\
\text { control }\end{array}$ & 467 & 283 & 55.2 & 901 & 143 & 478 & 337 & 57.1 & 951 & 153 \\
\hline \multicolumn{2}{|c|}{ L.S.D. at 0.05} & 7.51 & 8.39 & 2.18 & 19.36 & 2.01 & 25.45 & 9.82 & 2.64 & 33.58 & 3.74 \\
\hline \multicolumn{12}{|c|}{ Cultivar Isabella (I) $\quad$ Cultivar Milas $(\mathrm{M})}$. \\
\hline \multirow{2}{*}{\multicolumn{12}{|c|}{$\begin{array}{l}\text { Rizobacterien at a rate of } 2 \text { liter/feddan + Delfan (amino acids) at a rate of } 200 \mathrm{ppm} .(\mathrm{R} 1+\mathrm{D}) \text {. } \\
\text { Rizobacterien at a rate of } 4 \text { liter/feddan + Delfan (amino acids) at a rate of } 200 \mathrm{ppm} \text {. (R2+D). }\end{array}$}} \\
\hline & & & & & & & & & & & \\
\hline \multicolumn{12}{|c|}{ Rizobacterien at a rate of 2 liter/feddan. (R1) 4- Rizobacterien at a rate of 4 liter /feddan. (R2). } \\
\hline
\end{tabular}

The lowest vegetative growth was obtained when adding Rizobacterien at a rate of 2 liter/feddan. It can be concluded from the results that adding Rizobacterien at a rate of 4 liter/feddan + Delfan (amino acids) at a rate of 200 ppm increased the vegetative growth. The applied biofertilizers and amino acids to tomato plants increased vegetative which may be due to the increasing number of microorganisms living in the soil. Those microorganisms convert the organic materials in the soil to minerals such as nitrogen.

The interaction between the effect of biofertilizers and cultivars on vegetative growth are presented in Table (4). Results showed that the highest vegetative growth characters were obtained when applying Rizobacterien at a rate of $4 \mathrm{li}$ ter/feddan plus Delfan (amino acids) at a rate of 200 ppm with cultivar Isabella in comparison with other treatments during the two studied seasons.

The responses of cultivar Isabella to biofertilizers and amino acids were similar to the cultivar Milas by applying 4 liter/feddan from Rizobacterien. There were no significant differences in vegetative growth among the two cultivars during the two tested seasons. The lowest vegetative growth was obtained from adding Rizobacterien at a rate of 2 liter/feddan during the two studied seasons. This enhanced vegetative growth could be due to the increase of nutrient uptake from soil by roots. These results agreed with those of Phillps, (1971); Saber, (1996) and Awad, (1998); Abdalla, et al (2001) on pepper, Abou-Hussein, (2002) on potatoes, Adam, et al (2002) on cantaloupe, and Rizk, et al (2003) on squash.

\section{B. Effect of biofertilizers and cultivars on yield productivity of tomato plants grown under net- house conditions}

Early and total yield per plant and average fruit weight of tomato, as influenced by different biofertilizers rates and cultivars, are present in Table (5).

Data revealed that the cultivar Isabella gave higher early yield, total yield per plant and average fruit weight under rizobacterien at a rate of $4 \mathrm{li}$ ter/feddan + Delfan (amino acids) at a rate of 200 ppm, with significant differences between them over all other treatments.

The differences between cultivars were significant during the two studied seasons. However,there was no significant difference observed in number of fruit per plant for the two cultivars. Data of early and total yield per plant and average fruit weight (Table, 5) indicated that both yields 
Table 4. Effect of biofertilizers and cultivars interaction on vegetative growth characteristics of tomato plant leaves grown under net house conditions

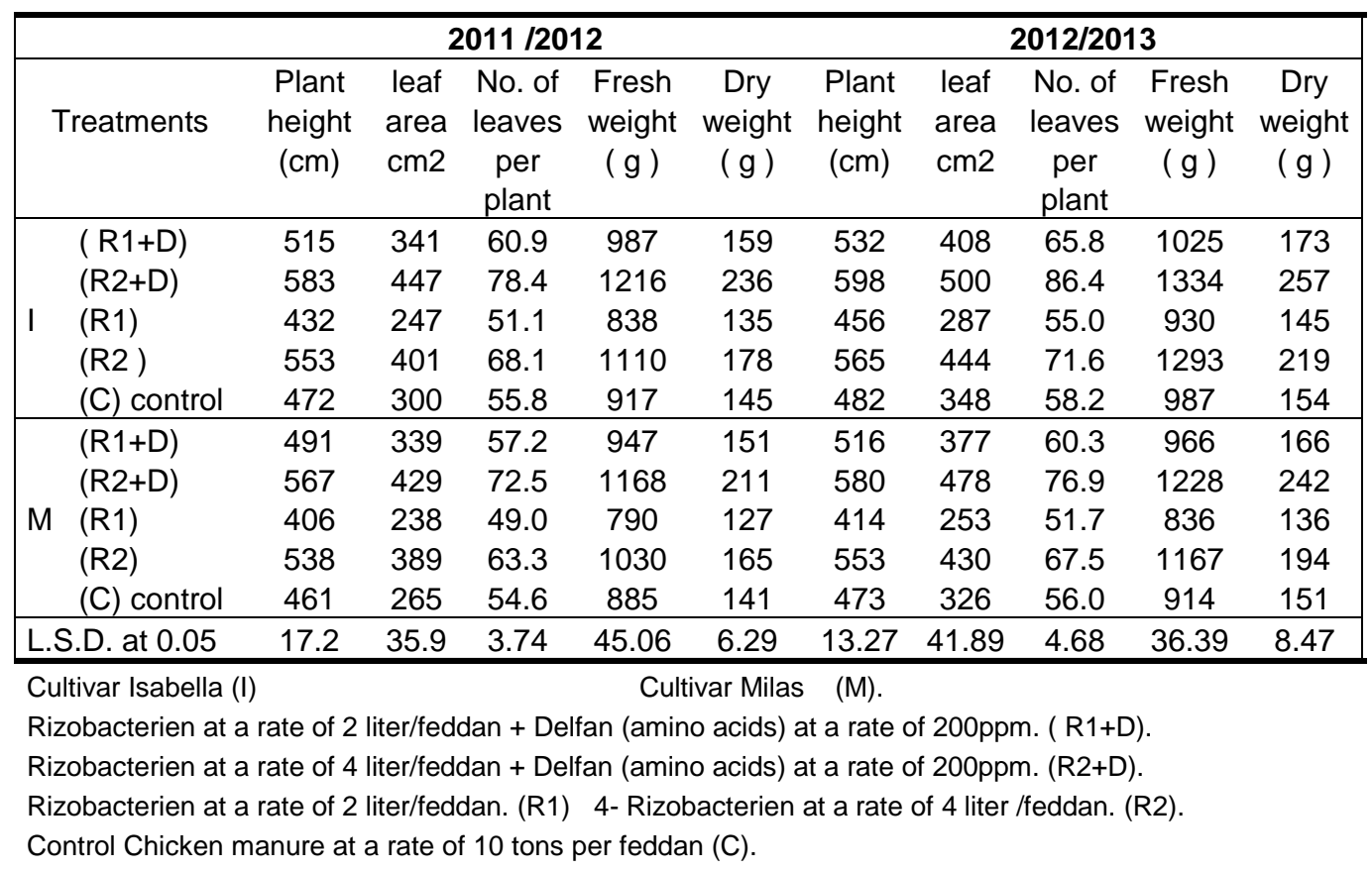

Table 5. Effect of biofertilizers and cultivars on yield and its compositions of tomato plant grown under net-house conditions

\begin{tabular}{|lcccccccc|}
\hline \multicolumn{1}{|c}{$2011 / 2012$} \\
\hline
\end{tabular}


were significantly higher with the applying of Rizobacterien at a rate of 4 liter/feddan + Delfan (amino acids) at a rate of $200 \mathrm{ppm}$, for the two cultivars compared with all studied treatments during the two seasons.

The lowest early yield, total yield per plant and average fruit weight were obtained from Rizobacterien at a rate of 2 liter/feddan. Number of fruits per plant showed no significant difference between all treatments and cultivars during the two studied seasons. Applying biofertilizers plus amino acid increased yield and the components of tomato crop. The effect might be due to the increase of nutrient elements in the soil. This increase can encourage the haulm growth, which increases the photosynthetic rates leading to an increase of assimilation rates. Similar results have been found by Saber (1996); Awad (1998); Shahaby (1981); Kumaraswany \& Madalageri (1990); Shahaby et al (1993); Valpin \& Kapulink (1994); Terry et al (1995); Batets et al (1999); Verranjaneyulu \& Kumari (2003); El-Shaabasi et al ( 2005); Ahmed et al (2006) and Hasanein \& Gaafer (2006).

The interaction between cultivars and biofertilizers (Table 6) revealed that the two cultivars gave higher early yield, total yield per plant and average fruit weight under Rizobacterien at a rate of $4 \mathrm{li}$ ter/feddan + Delfan (amino acids) at a rate of 200 ppm with significant difference between them and all other treatments. The increase of fruit yield when applying biofertilizers at a rate of $4 \mathrm{li}$ ter/feddan plus amino acids might be due to the increase of vegetative growth and nutrient elements content of plants, which consequently led to higher early and total yield. The results were in agreement with those of Hewedy (1999) on tomato, Abdalla, et al (2001) on pepper, AbouHussein (2002) on potatoes, Adam, et al (2002) on cantaloupe and Rizk, et al (2003) on squash.

C. Chemical composition of tomato fruits grown under net-house conditions

Ascorbic acid, total titratable acidity, total soluble solids and total chlorophyll of tomato fruits, as influenced by cultivars and different biofertilizers rates, are shown in Table (7). Data showed that such contents were significantly higher for Isabella cultivar than cv. Milas.

Adding Rizobacterien at a rate of 4 liter/feddan plus Delfan (amino acids) at a rate of $200 \mathrm{ppm}$ significantly increased ascorbic acid, total titratable acidity, total soluble solids and total chlorophyll than other treatments. However, the lowest values of the chemical composition parameters were obtained from adding rizobacterien at a rate of $2 \mathrm{li}$ - ter/feddan and with the control, chicken manure at a rate of 2.50 ton per feddans, and Rizobacterien at a rate of 2 liter/feddan + Delfan (amino acids) at a rate of $200 \mathrm{ppm}$, respectively. The results were confirmed in the two seasons and agreed with those obtained by Radwan, (1983) on tomato, Kabesh, et al (1987) on Soybean, Abdel Ati (1996) on potato and Hasanein and Gaafer (2006).

The interaction of biofertilizers and cultivars showed that applying Rizobacterien at a rate of 4 liter/feddan + Delfan (amino acids) at a rate of 200 ppm increased the values of chemical parameters significantly for the cultivar Isabella than the Milas cultivar. On the other hand, the lowest values were obtained from Rizobacterien at a rate of 2 liter/feddan for the two cultivars during the two studied seasons (Table 8).

From the previous results, it could be concluded that the best fruit quality was achieved for Isabella treated with Rizobacterien at a rate of $4 \mathrm{li}$ ter/feddan + Delfan (amino acids) at a rate of 200 ppm. Applying biofertilizers and amino acids increased chemical parameters. This effect could be due to that biofertilizers play a fundamental role in $\mathrm{P}$ or $\mathrm{K}$ fixed form to be soluble ready for plants, making the uptake of nutrients by plants more easy. Similar results were found by Shahaby et al (1993); Valpin \& Kapulink, (1994); Terry et al (1995); Awad, (1998); Ahmed et al (2006) and Hasanein \& Kabeel (2006).

D. Effect of biofertilizers and cultivars on water productivity of tomato plants grown under nethouse conditions

Cultivar Isabella gave significantly higher water productivity than cultivar Milas with significant effect during the two seasons (Table 9). As for the effect of biofertilizers and amino acids, data showed that applying Rizobacterien at a rate of 4 liter/feddan + Delfan (amino acids) at a rate of 200 ppm significantly increased water productivity than other treatments. Similar results were found by Radwan, (1983); Hewedy, (1999) on tomato and Abdrabbo et al (2009) on cucumber.

The lowest water productivity $\left(\mathrm{kg}\right.$ tomato/ $\mathrm{m}^{3}$ of water) was obtained from Rizobacterien at a rate of 2 liter/feddan. However, adding Rizobacterien at a rate of 4 liter/feddan + Delfan (amino acids) at a rate of $200 \mathrm{ppm}$ increased water productivity. This effect may be due to increase plant productivity due to improving the microorganisms living in the soil. 
Table 6. Effect of biofertilizers and cultivars interaction on yield and its compositions of tomato plant grown under net-house conditions

\begin{tabular}{|c|c|c|c|c|c|c|c|c|c|}
\hline & \multirow[b]{2}{*}{ Treatments } & \multicolumn{4}{|c|}{$2011 / 2012$} & \multicolumn{4}{|c|}{$2012 / 2013$} \\
\hline & & $\begin{array}{l}\text { Early } \\
\text { yield } \\
\mathrm{kg} / \text { plant }\end{array}$ & $\begin{array}{l}\text { No. of } \\
\text { fruit per } \\
\text { Plant }\end{array}$ & $\begin{array}{l}\text { Average } \\
\text { fruit } \\
\text { weight } \\
\text { (g) }\end{array}$ & $\begin{array}{l}\text { Total } \\
\text { yield } \\
\mathrm{kg} / \text { plant }\end{array}$ & $\begin{array}{l}\text { Early } \\
\text { yield } \\
\mathrm{kg} / \text { plant }\end{array}$ & $\begin{array}{l}\text { No. of } \\
\text { fruit Per } \\
\text { plant }\end{array}$ & $\begin{array}{l}\text { Average } \\
\text { fruit } \\
\text { weight } \\
\text { (g) }\end{array}$ & $\begin{array}{c}\text { Total } \\
\text { yield } \\
\mathrm{kg} / \text { plant }\end{array}$ \\
\hline \multirow{5}{*}{ I } & $(\mathrm{R} 1+\mathrm{D})$ & 1.96 & 37.6 & 175 & 6.58 & 1.83 & 40.7 & 169 & 6.89 \\
\hline & $(\mathrm{R} 2+\mathrm{D})$ & 2.87 & 39.3 & 195 & 7.67 & 2.64 & 42.0 & 188 & 7.92 \\
\hline & (R1) & 1.60 & 36.6 & 155 & 5.69 & 1.54 & 39.8 & 147 & 5.83 \\
\hline & (R2) & 2.33 & 39.3 & 186 & 7.283 & 2.19 & 43.0 & 172 & 7.40 \\
\hline & (C) control & 1.73 & 37.7 & 166 & 6.27 & 1.61 & 42.5 & 154 & 6.55 \\
\hline \multirow{5}{*}{ M } & $(\mathrm{R} 1+\mathrm{D})$ & 1.84 & 37.6 & 170 & 6.40 & 1.73 & 41.3 & 163 & 6.73 \\
\hline & $(\mathrm{R} 2+\mathrm{D})$ & 2.54 & 39.4 & 189 & 7.45 & 2.39 & 42.7 & 179 & 7.64 \\
\hline & (R1) & 1.54 & 35.4 & 148 & 5.23 & 1.41 & 39.3 & 136 & 5.36 \\
\hline & (R2) & 2.15 & 37.8 & 182 & 6.87 & 2.05 & 42.2 & 169 & 7.12 \\
\hline & (C) control & 1.66 & 37.3 & 161 & 5.99 & 1.56 & 42.6 & 147 & 6.25 \\
\hline & D.D. at 0.05 & 0.024 & N.S & 6.32 & 0.231 & 0.051 & N.S & 5.04 & 0.193 \\
\hline
\end{tabular}

Table 7. Effect of biofertilizers and cultivars on chemical composition of tomato fruits grown under nethouse conditions

\begin{tabular}{|c|c|c|c|c|c|c|c|c|c|}
\hline \multirow{2}{*}{\multicolumn{2}{|c|}{ Treatments }} & \multicolumn{4}{|c|}{$2011 / 2012$} & \multicolumn{4}{|c|}{$2012 / 2013$} \\
\hline & & \multirow{2}{*}{$\begin{array}{c}\begin{array}{c}\text { ascorbic } \\
\text { acid } \\
\text { mgl100g } \\
\text { f. w. }\end{array} \\
19.2\end{array}$} & \multirow{2}{*}{$\begin{array}{c}\text { total } \\
\text { acidity } \\
\text { TA } \\
\% \\
37.8\end{array}$} & \multirow{2}{*}{$\begin{array}{c}\begin{array}{c}\text { total } \\
\text { soluble } \\
\text { solids } \\
\%\end{array} \\
40.3\end{array}$} & \multirow{2}{*}{$\begin{array}{c}\text { total } \\
\text { chlorophyll } \\
\text { content }\end{array}$} & \multirow{2}{*}{$\begin{array}{c}\begin{array}{c}\text { Ascorbic } \\
\text { acid } \\
\text { mg } \backslash 100 \mathrm{~g} \\
\text { f. w. }\end{array} \\
18.1\end{array}$} & \multirow{2}{*}{$\begin{array}{c}\begin{array}{c}\text { Total } \\
\text { acidity } \\
\text { TA }\end{array} \\
36.1\end{array}$} & \multirow{2}{*}{$\begin{array}{c}\begin{array}{c}\text { Total } \\
\text { soluble } \\
\text { solids } \\
\%\end{array} \\
38.8\end{array}$} & \multirow{2}{*}{$\begin{array}{c}\begin{array}{c}\text { Total } \\
\text { chlorophyll } \\
\text { content }\end{array} \\
37.7\end{array}$} \\
\hline A & 1 & & & & & & & & \\
\hline & $\mathrm{M}$ & 18.2 & 36.6 & 39.1 & 37.9 & 16.6 & 34.3 & 37.0 & 35.3 \\
\hline & S.D. at 0.05 & 0.67 & 0.31 & 0.74 & 1.63 & 0.45 & 0.19 & 0.22 & 0.94 \\
\hline \multirow{5}{*}{ B } & $(\mathrm{R} 1+\mathrm{D})$ & 18.7 & 37.2 & 40.1 & 39.1 & 17.6 & 35.4 & 38.7 & 37.8 \\
\hline & $(\mathrm{R} 2+\mathrm{D})$ & 21.8 & 33.0 & 45.0 & 42.7 & 19.7 & 30.7 & 43.5 & 40.4 \\
\hline & (R1) & 15.9 & 42.0 & 34.1 & 35.4 & 14.5 & 40.4 & 32.8 & 30.9 \\
\hline & (R2) & 19.6 & 34.9 & 41.7 & 41.4 & 18.9 & 32.3 & 39.4 & 38.9 \\
\hline & (C) control & 17.4 & 39.4 & 37.0 & 37.1 & 15.9 & 37.6 & 35.4 & 34.5 \\
\hline & S.D. at 0.05 & 1.05 & 2.48 & 2.91 & 1.58 & 0.86 & 2.07 & 3.01 & 1.83 \\
\hline \multicolumn{10}{|c|}{$\begin{array}{l}\text { Cultivar Isabella (I) } \\
\text { Rizobacterien at a rate } \\
\text { Rizobacterien at a rate } \\
\text { Rizobacterien at a rate } \\
\text { Control Chicken manu }\end{array}$} \\
\hline
\end{tabular}


The Effect of Bio-Fertilizers and Amino Acids on Tomato Production under Net-House Conditions 51

Table 8. Effect of biofertilizers and cultivars interaction on chemical composition of tomato fruits grown under net-house conditions

\begin{tabular}{|c|c|c|c|c|c|c|c|c|c|}
\hline \multirow{2}{*}{\multicolumn{2}{|c|}{ Treatments }} & \multicolumn{4}{|c|}{$2011 / 2012$} & \multicolumn{4}{|c|}{$2012 / 2013$} \\
\hline & & $\begin{array}{l}\text { ascorbic } \\
\text { acid } \\
\text { mg } \backslash 100 \mathrm{~g} \\
\text { f. w. }\end{array}$ & $\begin{array}{c}\text { Total } \\
\text { Acidity } \\
\%\end{array}$ & $\begin{array}{c}\text { Total } \\
\text { Soluble } \\
\text { Solids } \\
\%\end{array}$ & $\begin{array}{l}\text { Total } \\
\text { chlorophyll } \\
\text { content }\end{array}$ & $\begin{array}{l}\text { Ascorbic } \\
\text { acid } \\
\text { mg } \backslash 100 \mathrm{~g} \\
\text { f. w. }\end{array}$ & $\begin{array}{c}\text { Total } \\
\text { Acidity } \\
\%\end{array}$ & $\begin{array}{c}\text { Total } \\
\text { Soluble } \\
\text { Solids } \\
\%\end{array}$ & $\begin{array}{l}\text { total } \\
\text { chlorophyll } \\
\text { content }\end{array}$ \\
\hline \multirow{5}{*}{ I } & $(\mathrm{R} 1+\mathrm{D})$ & 19.1 & 37.9 & 40.3 & 40.0 & 18.5 & 36.4 & 38.7 & 39.6 \\
\hline & (R2+D) & 22.6 & 33.9 & 46.5 & 43.3 & 20.4 & 31.7 & 45.1 & 41.4 \\
\hline & (R1) & 16.3 & 42.3 & 34.9 & 380 & 15.4 & 41.3 & 33.5 & 31.5 \\
\hline & (R2) & 20.2 & 34.9 & 42.2 & 41.9 & 19.8 & 33.2 & 40.4 & 40.4 \\
\hline & (C) control & 17.8 & 39.9 & 37.5 & 38.5 & 16.2 & 38.1 & 36.2 & 35.4 \\
\hline \multirow{5}{*}{ M } & (R1+D) & 18.3 & 36.4 & 39.9 & 38.1 & 16.7 & 34.4 & 38.6 & 36.1 \\
\hline & $(\mathrm{R} 2+\mathrm{D})$ & 21.0 & 32.0 & 43.5 & 42.0 & 19.0 & 29.6 & 41.9 & 39.4 \\
\hline & (R1) & 15.5 & 40.8 & 33.3 & 33.1 & 13.5 & 39.5 & 32.0 & 30.3 \\
\hline & (R2) & 19.0 & 34.8 & 41.1 & 40.8 & 18.1 & 31.4 & 38.3 & 37.3 \\
\hline & (C) control & 16.9 & 38.9 & 36.4 & 35.7 & 15.5 & 37.0 & 34.5 & 33.5 \\
\hline & D.D. at 0.05 & 0.63 & 0.94 & 1.61 & 1.79 & 0.51 & 1.49 & 0.73 & 2.17 \\
\hline \multicolumn{10}{|c|}{$\begin{array}{l}\text { Cultivar Isabella (I) Cultivar Milas (M). } \\
\text { Rizobacterien at a rate of } 2 \text { liter/feddan + Delfan (amino acids) at a rate of 200ppm. ( R1+D). } \\
\text { Rizobacterien at a rate of } 4 \text { liter/feddan + Delfan (amino acids) at a rate of } 200 \mathrm{ppm} .(\mathrm{R} 2+\mathrm{D}) \text {. } \\
\text { Rizobacterien at a rate of } 2 \text { liter/feddan. (R1) } 4 \text { - Rizobacterien at a rate of } 4 \text { liter /feddan. (R2). } \\
\text { Control Chicken manure at a rate of } 10 \text { tons per feddan (C). }\end{array}$} \\
\hline
\end{tabular}

Table 9. Effect of biofertilizers and cultivars on water productivity of tomato plants grown under net-house conditions

\begin{tabular}{|cccc|}
\hline & & $\mathbf{2 0 1 1 / 2 0 1 2}$ & $\mathbf{2 0 1 2 / 2 0 1 3}$ \\
\hline & Treatments & $\mathrm{kg} / \mathrm{m}^{3}$ & $\mathrm{~kg} / \mathrm{m}^{3}$ \\
\hline $\mathrm{A}$ & $\mathrm{I}$ & 16.7 & 17.2 \\
\hline & $\mathrm{M}$ & 15.9 & 16.5 \\
\hline & L.S.D. at 0.05 & 0.44 & 0.16 \\
\hline & (R1+D) & 16.1 & 16.9 \\
\hline & (R2+D) & 18.8 & 19.3 \\
\hline B & (R1) & 13.6 & 13.9 \\
\hline & (R2) & 17.6 & 18.0 \\
\hline & (C) control & 15.2 & 15.9 \\
\hline & L.S.D. at 0.05 & 0.63 & 0.74 \\
\hline
\end{tabular}

Cultivar Isabella (I) Cultivar Milas (M).

Rizobacterien at a rate of 2 liter/feddan + Delfan (amino acids) at a rate of 200ppm. ( R1+D). Rizobacterien at a rate of 4 liter/feddan +

Delfan (amino acids) at a rate of 200ppm. (R2+D). Rizobacterien at a rate of 2 liter/feddan. (R1)

4- Rizobacterien at a rate of 4 liter /feddan. (R2). Control Chicken manure at a rate of 10 tons per feddan (C).

The interaction of biofertilizers and cultivars on water productivity are present in Table (10). Results showed that applying Rizobacterien at a rate of 4 liter/feddans + Delfan (amino acids) at a rate of $200 \mathrm{ppm}$ increased water productivity during the two studied seasons. These results agreed with Abdrabbo, (2007) who concluded that applying such agriculture practices i.e. use proper cultivar and appropriate organic fertilizers led to the improve of water productivity due to the increase of plant yield.
Table 10. Effect of biofertilizers and cultivars interaction on water productivity of tomato plant grown under net house conditions

\begin{tabular}{|c|c|c|c|}
\hline & & $2011 / 2012$ & 2012/2013 \\
\hline & Treatments & $\mathrm{kg} / \mathrm{m}^{3}$ & $\mathrm{~kg} / \mathrm{m}^{3}$ \\
\hline & $(\mathrm{R} 1+\mathrm{D})$ & 16.4 & 17.1 \\
\hline & $(\mathrm{R} 2+\mathrm{D})$ & 19.1 & 19.7 \\
\hline I & (R1) & 14.1 & 14.5 \\
\hline & (R2) & 18.1 & 18.4 \\
\hline & (C) control & 15.6 & 16.3 \\
\hline & $(\mathrm{R} 1+\mathrm{D})$ & 15.9 & 16.7 \\
\hline & $(\mathrm{R} 2+\mathrm{D})$ & 18.5 & 19.0 \\
\hline M & (R1) & 13.0 & 13.3 \\
\hline & (R2) & 17.1 & 17.7 \\
\hline & (C) control & 14.9 & 15.5 \\
\hline & L.S.D. at 0.05 & 0.69 & 0.42 \\
\hline
\end{tabular}

Cultivar Isabella (I) Cultivar Milas (M).

Rizobacterien at a rate of 2 liter/feddan +

Delfan (amino acids) at a rate of 200ppm. (R1+D).

Rizobacterien at a rate of 4 liter/feddan +

Delfan (amino acids) at a rate of 200ppm. (R2+D).

Rizobacterien at a rate of 2 liter/feddan. (R1)

4- Rizobacterien at a rate of 4 liter /feddan. (R2).

Control Chicken manure at a rate of 10 tons per feddan (C).

\section{CONCLUSION}

Tomato fertilized with rizobacterien at a rate of 4 liter/feddan + Delfan (amino acids) at a rate of 200 ppm gave higher plant length, higher number of leaves per plant, higher leaf area, and higher fresh and dry weight. This treatment enhanced tomato production as it increased total and marketable yields, beside the increase of yield compo- 
nents, when compared with other fertilizer treatments. Regarding water productivity for the water unit, it is consider a vital subject under arid climate conditions with scarcity of water. This study recommends the use of advanced agronomic practices in tomato production which include cover greenhouse with nets, select the proper cultivar (Isabella) and apply the proper concentration of bio fertilizers (Delfan amino acid (200ppm)).

\section{REFERENCES}

Abdrabbo, M.A.A., Hassanein, M.K. and Medany. M.A. (2007). Effect of Irrigation Regime and Compost Level on Potato Production in Northern Delta, Egypt. Proceeding of the 7th African Potato Association Conference/Exhibition, Alexanderia, Egypt. 85-197.

Abdrabbo, M.A.A., Farag, A.A. and Hassanein M.K. (2009). Irrigation requirements for cucumber under different mulch colors. Egypt. J. Hort. 36: 333-346.

Abdalla A.M., Rizk Fatma A., Adam, Safia M. (2001). The productivity of pepper plants as influenced by some bio-fertilizer treatments under plastic house conditions. Bull. Fac. Agric., Cairo Univ., 52: 625-640.

Abdel Ati, S.A. (1996). Influence of some organic fertilizers on growth and yield of pepper plants, Capsicum annuum, L. cultivated under plastic houses. M.Sc. Thesis, Fac. Agric., Ain Shams Univ., Cairo, Egypt.

Abou-Hussein, S.D. (2002). Studies on potato fertigation in newly reclaimed lands. M.Sc thesis, Fac. Agric., Ain Shams Univ. 93 p.

Adam Safia. M., Abdalla, A.M., Rizk Fatma. A. (2002). Effect of the interaction between the mineral and bio-fertilizer on the productivity of cantaloupe (Cucumismelo L.) under the newly reclaimed soils conditions. Egypt. J. Hort., 29(2): 301-315.

Ahmed, M.E., El-Zeiny, O.A.H. and Zaky, M.H. (2006). Studies on the effect of vitamin B and some amino acids on growth, yield and chemical composition of sweet pepper. Egypt J. of Appl. Sci., 21(4): 567-581.

A.O.A.C. (1990). Association of official analysis chemists. Official methods of analysis $15^{\text {th }} \mathrm{BD}$. Washington DC, USA.

Allen, R.G., Pereira L.S., Raes D. and Smith, M. (1998). "Crop evapotranspiration: guidelines for computing crop waterrequirements", FAO Irrigation and Drainage Paper 56, Rome, 300 p.
Awad, F.K., Khalil, W. and Maksoud, A.H. (1993). Comparative effects of some organic manures and bentonite as soil amendments. Agrochemical, 37: 101-106.

Awad, N.M. (1998). The use of microorganisms in ecological farming systems. Ph.D. Thesis, Fac. Sci. Cairo Univ., Egypt.

Batets, L.S., Waldern, R.P. and Teare, I.D. (1999). Rapid determination of free proline for water stress studies. Plant and Soil, 8(7): 939956.

El-Shaabasi, M.S.S., Mohamed, S.M.A. and Mahfouz Sanna, A. (2005). Effect of foliar spray with some amino acids on growth, yield and chemical composition of tomato plant. 6th Arabian Conference for hort. Ismalia Egypt. pp. 16-24.

FAO, (1988). World Agriculture toward 2000: an FAO Study. Belhaven Press, London.

Gomez, K.A. and Gomez, A.A. (1984). Statistical procedures for agricultural research. A WileyInterscience Publication, John Wiley \& Sons, USA.

Hasanein, N.M. and Gaafer, S.A. (2006). The effect of organic manure, amino acids and sulfur on water melon vegetative growth and yield grown under winter low plastic tunnels. Egypt J. of Appl. Sci., 21(9): 54-67.

Hasanein, N.M. and Kabeel, S.M.A. (2006). Increasing potato productivity grown in sandy soil through organic and biofertilizers applications. J. Agric. Sci. Mansoura Univ., 31(2): 951962.

Hashem, F.A. (2007). Studies on Water Requirements and Nitrogen Fertilization for Cucumber under Protected Cultivation. M.Sc. Ain Shams University, Egypt. 33 p.

Hewedy, A.M. (1999). Influence of single and multi bacterial fertilizer on the growth and fruit yield of tomato. Egypt J. Appl. Sci.,14(7):1999.

Kabesh, M.O., Saber, M.S.M. and Behaity O. (1987). Utilization of biofertilizers in field crop production. 1. Effect of increasing rates of phosphatic fertilizers with / and without biofertilizations on growth of soybean plants using pot experiment. Egypt. J. Agron. 12: 123-130.

Kumaraswany, D. and Madalageri, B.B. (1990). Effect of Azotobacterinoculation on tomato. South India Hort. 38: 345-346.

Maheswari, T.U., K. Haripriya, P. Poonkodi and Kamalakannan S. (2004). Effect of foliar application of organic nutrients on some quality indices and economics of chilli (Capsicum annuum L.). Advances-in-Plant-Sci., 17: 259-262. 
Michael, A.M. (1978). Irrigation Theory and Practicies. Vikas Publishing House, New Delhi.

Phillps, J.D.J. (1971). Introduction of the biochemistry and physiology of plant growth hormones. Mc.Grow Hill Book Crop New York, London, Toronto and Sydney, 12 p.

Radwan, S.M.A. (1983). Effect of inoculation with phosphate dissolving bacteria on some nutrients uptake from newly cultivated soils. M.Sc. Thesis, Fac. Agric. Ain Shams Univ., Egypt.

Rizk Fatma, A., Shafeek, M.R. and Helmy, Y.I. (2003). A comparative study between the application of bio and/or mineral fertilizers with squash plant. Egypt. J. Appl. Sci., 18(4A): 257-269.

Saber, M.S.M. (1996). Bio fortified farming systems for sustainable agriculture and improved environment. Global Environmental Biotechnology Approaching the year 2000, Inter. Soc. for Environ. Biotech. July 15-20 Boston, USA.
Shahaby, A.F.E. (1981). N2-fixing bacteria in the rhizosphere of certain plants. M.Sc. Thesis, Fac. Agric. Cairo Univ. Egypt.

Shahaby, A.F.E., Amin, G. and Khalafallah, G.M. (1993). Response of rice and tomato seedlings to inoculation with diazotrophs and their culture filtrates. The Sixth inter. Sym. on Nit. Fix. With Non- Legumes Ismailia Egypt (1993).

Terry, E., Pino M., Delos A. and Medina, N. (1995). Biofertilizers application in early season tomato cultivation. En. epocatemprana. Cult. Tropical 16(3): 69-71.

Volpin, H. and Kapulnik Y. (1994). Interaction of Azospirillum with beneficial soil microorganisms. Azospirillum Plant Association Ed. Y. Okan. pp. 111-116. CRC Press. Boca Raton.

Verranjaneyulu, K. and Kumari, B.D.R. (2003). Proline metabolism during water stress in mulberry. J. Exper. Botany India 40(2/4) : 581. 